\title{
Petroleum ether extract of Chenopodium album L. prevents cell growth and induces apoptosis of human lung cancer cells
}

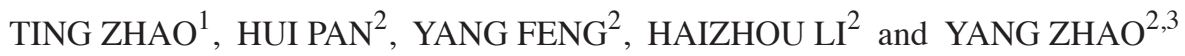 \\ ${ }^{1}$ Faculty of Environmental Science and Engineering; ${ }^{2}$ Faculty of Life Science and Technology, \\ Kunming University of Science and Technology, Kunming, Yunnan 650500; ${ }^{3}$ Institute of Plant Physiology \& Ecology, \\ Shanghai Institutes for Biological Sciences, Chinese Academy of Sciences, Shanghai 20000, P.R. China
}

Received July 29, 2015; Accepted September 13, 2016

DOI: $10.3892 /$ etm.2016.3765

\begin{abstract}
Chenopodium album L. is a common edible herb distributed in China that has been used as a traditional Chinese medicine for antiviral, antifungal, anti-inflammatory and cancer treatment. However, to the best of our knowledge no previous reports have investigated its the function of its phytochemical extracts in lung cancer cells. The purpose of the present study was to assess the anticancer activities of the phytochemical extracts of C. album L. on human non-small cell lung cancer A549 cells. The present findings demonstrated that the petroleum ether (PE) extract of C. album L. exhibited significant growth inhibitory effects on A549 with an $\mathrm{IC}_{50}$ value of $33.31 \pm 2.79 \mu \mathrm{g} / \mathrm{ml}$. As determined by MTT and colony formation assays, its growth inhibitory effects were dose- and time-dependent. Furthermore, PE extract-treated A549 cells exhibited dose-dependent cell growth arrest at the G1 phase of the cell cycle and cell apoptosis was induced. These results provide useful data on the anticancer activities of C. album $\mathrm{L}$. in human lung cancer and demonstrated the novel possibilities of this plant in developing lung cancer therapies.
\end{abstract}

\section{Introduction}

Lung cancer, as one of the most malignant tumors, has a huge social and economic impact on human health in China and the world (1). According to statistics from the National Office on Tumor Cure and Prevention of China, 700,000 people die of lung cancer annually (2). Despite notable advances in the diagnosis and treatment of lung cancer, many of the chemotherapeutic drugs currently used to treat lung cancer are either not highly effective or may lose their efficacies due to the

Correspondence to: Professor Yang Zhao, Faculty of Life Science and Technology, Kunming University of Science and Technology, 727 Jing Ming Road, Chenggong, Kunming, Yunnan 650500 P.R. China

E-mail: yangzhao@sibs.ac.cn

Key words: Chenopodium album L., non-small cell lung cancer cell A549, petroleum ether extract, G1 phase arrest, apoptosis development of drug resistance (3). Hence, it is important to discover and develop novel drugs for lung cancer treatment.

Natural chemicals have much more chemical diversity than synthetic ones, and have long been recognized as privileged scaffolds to develop drugs due to their evolved biological target specificities, and their proven biological targets are predominantly diverse functional proteins of organisms $(4,5)$. Natural chemical library screenings typically yield higher hit rates of drug-like active compounds than ones that are acquired from synthetic molecule library screenings (6). Previous studies have demonstrated that phytochemical extracts or mixtures from several medicinal herbs exhibit anticancer activities in vitro or in vivo and are valuable natural sources for drug-like active natural compound screenings (7-10).

Chenopodium album Linne is a fast-growing annual weedy plant, belonging to the Chenopodium family, which is widely distributed in hot sub-tropical and tropical climates, as well as temperate regions of the world. Studies on various phytochemical constituents of $C$. album have indicated that the plant contains phytochemicals with various pharmacological effects, including antiviral, antifungal, antioxidant, anti-inflammatory, antiallergic and antiseptic activities (11-13). However, to date little research pertaining to the possible anticancer phytochemical constituents of this plant has been performed. Khoobchandani et al (14) reported that the ethyl acetate and methanol extracts of $C$. album prevented the cell growth of human breast cancer MCF-7 cells. Although folk medical usage of C. album L. in China has been documented, there are no reports of its phytochemical extracts on the possible activity against lung cancer. The present study used medicinal plant phytochemical extract library screening to identify the petroleum ether (PE) extract of C. album L. in order to investigate its effects on the proliferation and cell cycle progression of A549 cells. The present results may provide data to support the use of phytochemicals from C. album L. to develop novel cancer therapies.

\section{Materials and methods}

Preparation of the extracts of plants. Medicinal plant materials were acquired from the wild in Kunming (Yunnan, China) during the summer of 2014 to prepare a phytochemical extract library, which was identified by Dr. Haizhou Li from 
the Faculty of Life Science and Technology of Kunming University of Science and Technology (Kunming, China). For the preparation of the phytochemical extracts, the plant materials, including branches and leaves, were washed, dried, and finely chopped and grinded. The samples were first extracted with $95 \%$ ethanol by an ultrasonic method (15), and were subsequently evaporated using a rotary evaporator (EYELA, Tokyo, Japan). Following this, the dried material was successively extracted using PE, and was subsequently treated with chloroform, ethyl acetate, n-butyl alcohol in a Soxhlet extractor (EYELA). Extracts were filtered and concentrated using a rotary evaporator to evaporate until they were dry. All the dried extracts were weighed and solved with $99.9 \%(\mathrm{v} / \mathrm{v})$ DMSO (Beyotime Institute of Biotechnology, Haimen, China) to prepare stock solutions at concentration of $100 \mathrm{mg} / \mathrm{ml}$. Subsequently, $100 \mu \mathrm{l}$ of each phytochemical stock solution was allotted into each well of a 96-well microplate to form a phytochemical extract screening library.

Cell lines and culture. Human non-small cell lung cancer A549 cell line was purchased from the Kunming Institute of Zoology, Chinese Academy of Sciences (Kunming, China). A549 cells were maintained in RPMI 1640 medium supplemented with $10 \%$ (v/v) fetal calf serum (ScienCell Research Laboratories, Inc., Carlsbad, CA, USA) and $100 \mathrm{U} / \mathrm{ml}$ penicillin and streptomycin (Solarbio Science \& Technology Co., Ltd., Beijing, China), asnd were incubated at $37^{\circ} \mathrm{C}$ in a humidified incubator (Thermo Fisher Scientific, Inc., Waltham, MA, USA) with $5 \% \mathrm{CO}_{2}$ supplementation.

Anticancer phytochemical extract screening and $I C_{50} S$ determination. A549 cells in $100 \mu 1$ medium were seeded in a $96-$-well plate at a density of $5 \times 10^{3}$ cells/well. Following $24 \mathrm{~h}$, the cells were either treated with phytochemical extracts at different concentrations $(3.91,7.81,15.63,31.5$, $62.5,125,250$ and $500 \mu \mathrm{g} / \mathrm{ml}$ ) for 24,48 and $72 \mathrm{~h}$, respectively, or treated with $0.5 \%$ DMSO as controls. Subsequently, $5 \mathrm{mg} / \mathrm{ml}$ MTT (Sigma-Aldrich; Merck Millipore, Darmstadt, Germany) solution was added into each well and incubated for $4 \mathrm{~h}$. Following this, the supernatant in each well was discarded and $100 \mu 1$ DMSO was added. Optical density of each culture was measured at $490 \mathrm{~nm}$ using a microplate reader (Infinte-M200 Pro; Thermo Fisher Scientific, Inc.). The percentage of cell growth inhibition was calculated using the following formula: Percentage of cell growth inhibition $=(\mathrm{C}-\mathrm{T}) / \mathrm{C} \times 100$, where $\mathrm{C}$ denotes absorbance of control cells and $\mathrm{T}$ denotes absorbance of treatment cells. Data were presented in percentages of cell inhibition relative to the control. Percentage of cell growth inhibition was used to determine the $\mathrm{IC}_{50}$ values of the anticancer activity of phytochemical extracts using Probit analysis with GraphPad Prism 5.0 software (GraphPad Software, San Diego, CA, USA).

Colony formation assay. A549 cells were plated in 6-well plates at a density of 200 cells/well. Each culture was mixed with a PE extract at concentrations of $0,16.5,31.5,62.5,125$ and $250 \mu \mathrm{g} / \mathrm{ml}$ respectively. Following 12 days of incubation, the cell colonies formed in each well were stained with crystal violet (Beyotime Institute of Biotechnology) after fixation with formaldehyde, and the number of colony formed in each well was manually counted.

Morphological observation of A549 cells treated with a PE extract. Morphology of A549 cells treated with a PE extract concentrations of 62.5 or $31.25 \mu \mathrm{g} / \mathrm{ml}$, or with $0.5 \%$ DMSO control for $72 \mathrm{~h}$ was observed under a bright field using an inverted fluorescence microscope (Olympus Corp., Tokyo, Japan) at x200 magnification.

Briefly, A549 cells were cultured in 24-well plates at $1 \times 10^{4}$ cells/well and were analyzed following 24 -h treatment with PE extract (31.25 and $62.5 \mu \mathrm{g} / \mathrm{ml}$, respectively). Treated cells were fixed with cold $4.0 \%$ formaldehyde for $10 \mathrm{~min}$, washed with phosphate-buffered saline (PBS), and incubated with $10 \mu \mathrm{M}$ Hoechst 33342 (Sigma-Aldrich; Merck Millipore) at $37^{\circ} \mathrm{C}$ for $15 \mathrm{~min}$. Subsequently, the cells were washed with PBS and the cell nuclei were observed under a fluorescence microscope (Olympus Corp.).

Cell cycle analysis. A549 cells at 50-60\% confluence were treated with a phytochemical extract at concentrations of 31.25 and $62.5 \mu \mathrm{g} / \mathrm{ml}$, respectively, for $24 \mathrm{~h}$. Cells were subsequently harvested by trypsinization and washed twice with PBS. Afterwards, the cells were fixed with cold $70 \%$ ethanol for $24 \mathrm{~h}$ at $4^{\circ} \mathrm{C}$ and centrifuged at $1,000 \mathrm{x} g$ for $5 \mathrm{~min}$. Cell pellets were collected and washed with cold PBS. Finally, the cells were suspended in $500 \mu \mathrm{l}$ staining buffer of $50 \mu \mathrm{g} / \mathrm{ml}$ propidium iodide (PI) with $100 \mu \mathrm{g} / \mathrm{ml} \mathrm{RNaseA} \mathrm{(Beyotime} \mathrm{Institute} \mathrm{of}$ Biotechnology), and incubated at $37^{\circ} \mathrm{C}$ for $30 \mathrm{~min}$ in the dark. Cell cycle progression was then analyzed by a flow cytometer (BD Biosciences, San Jose, CA, USA). A minimum of 10,000 cells were used for each assay and DNA content histograms were further analyzed by FlowJo 7.6 software (Tree Star, Inc., Ashland, OR, USA) for cell cycle analysis.

Cell apoptosis assays. Prepared A549 cells were cultured in 6 -well plates at a density of $5 \times 10^{5}$ cells $/ \mathrm{ml}$ and were treated with a PE extract at concentrations of 31.25 and $62.5 \mu \mathrm{g} / \mathrm{ml}$, respectively, for $24 \mathrm{~h}$. Following treatment, the cells were collected and washed with $1 \mathrm{ml}$ cold PBS, and were resuspended with $250 \mu 1$ staining buffer (Beyotime Institute of Biotechnology) with Annexin V/fluorescein isothiocyanate $(5 \mu \mathrm{l})$ and PI $(10 \mu 1,20 \mu \mathrm{g} / \mathrm{ml})$. Cells were incubated at $37^{\circ} \mathrm{C}$ in the dark for $15 \mathrm{~min}$. Finally, the stained cells were analyzed using a flow cytometer. Data were analyzed by FlowJo 7.6 software.

Statistical analysis. All data were presented as the mean \pm standard deviation. Student's t-tests were performed to analyze the significant difference between treatment and control data. $\mathrm{P}<0.05$ was considered to indicate a statistically significant difference.

\section{Results}

Growth inhibitory effects of C. album L. extracts on A549 cells. Cytotoxic activities against A549 cell growth following treatment with phytochemical extracts of PE, chloroform, ethyl acetate, and n-butyl alcohol of C. album $\mathrm{L}$. at concentrations of $3.91,7.81,15.63,31.25,62.5,125,250$ and $500 \mu \mathrm{g} / \mathrm{ml}$ were 
Table I. $\mathrm{IC}_{50}$ values of extracts of Chenopodium album L. and gemcitabine on A549 cell growth.

\begin{tabular}{lc}
\hline Samples & $\mathrm{IC}_{50}$ values $(\mu \mathrm{g} / \mathrm{ml})$ \\
\hline Petroleum ether extract & $33.31 \pm 2.79$ \\
Chloroform extract & $84.96 \pm 5.43$ \\
Ethyl acetate extract & $304.79 \pm 3.92$ \\
N-butyl alcohol extract & $\mathrm{ND}$ \\
Gemcitabine & $0.45 \pm 1.28$ \\
\hline
\end{tabular}

$\mathrm{IC}_{50}$ values of each extracts of Chenopodium album $L$. or gemcitabine (positive control) were acquired via dose inhibitory assays of A549 cell growth. ND, not determined. Data presented as the mean \pm standard deviation of six replicates $(\mathrm{n}=6)$. $\mathrm{IC}_{50}$, half maximal inhibitory concentration.

screened and measured respectively for $72 \mathrm{~h}$. Gemcitabine treatment was used as a positive control for cytotoxicity (Table I). The $\mathrm{IC}_{50}$ values of these extracts of $C$. album $\mathrm{L}$. toward A549 cell growth were calculated and the PE extract of C. album L. exhibited the strongest cell growth inhibitory effect with the lowest $\mathrm{IC}_{50}$ value of $33.31 \pm 2.79 \mu \mathrm{g} / \mathrm{ml}$ among the extracts screened (Table I). Dose effect assays showed the PE extract of C. album L. repressed A549 cell growth in a dose-dependent manner (Fig. 1A). Time effect assays demonstrated that the PE extract of C. album L. inhibited A549 cell growth in a time-dependent manner at the various extract concentrations tested (Fig. 1B). These results demonstrated the PE extract of C.album L. had a potent and specific growth inhibitory effect on A549 cells.

Inhibitory effects of the PE extract of C. album L. on colony formation in A549 cells. The capability of cell colony formation may represent cell viability after cell inoculation and indicate how cell growth depends on the cell population and the ability of cell propagation. When A549 cells were treated with increasing concentrations of the PE extract of C. album L. from 7.81, $15.63,31.25$ and 62.5 to $125 \mu \mathrm{g} / \mathrm{ml}$, the number of the cell colonies formed was reduced in a dose-dependent manner (Fig. 2). These results demonstrated that the colony formation and cell propagation abilities of A549 cells were sensitive to the treatment of PE extract of C. album $\mathrm{L}$.

Morphological changes of A549 cells treated with the PE extract of C. album L. When comparing the morphological properties of control A549 cells treated with $0.5 \%$ DMSO and the PE-treated A549 cells, the morphologies of A549 cells treated with the PE extract of $C$. album L. at concentrations of 31.25 and $62.5 \mu \mathrm{g} / \mathrm{ml}$ for $24 \mathrm{~h}$ exhibited apoptotic-associated cellular phenotypes, including cell roundness and shrinkage (Fig. 3). PE extract treatment induced the nuclear compaction of A549 cells, whereas the control cells treated with $0.5 \%$ DMSO showed normal nuclear morphology (Fig. 4). These cellular phonotypical results indicated that treatment with the PE extract of C. album L. may have induced A549 cell apoptosis.

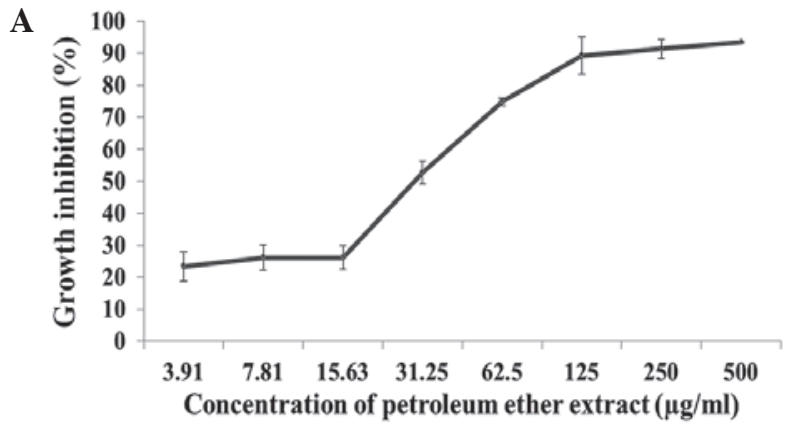

B

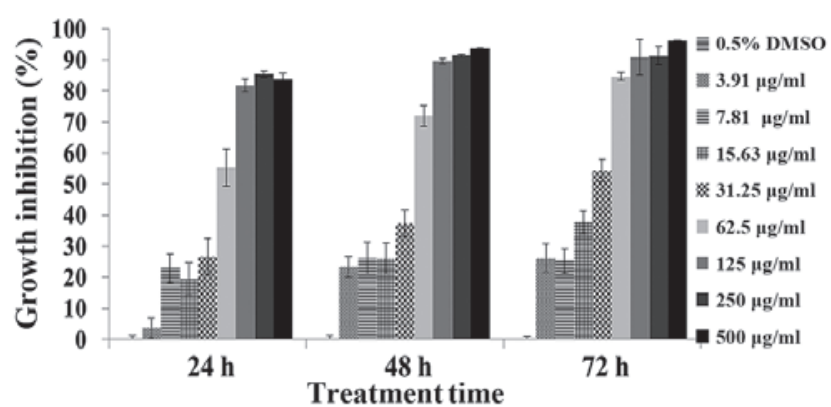

Figure 1. Growth inhibitory effects of the PE extract of Chenopodium album L. on A549 cells. (A) Growth inhibition percentages of A549 cells treated with the PE extract at 7.81, 15.63, 31.25, 62.5, 125,250 and $500 \mu \mathrm{g} / \mathrm{ml}$, respectively, for $72 \mathrm{~h}$. (B) Growth inhibition percentages of A549 cells treated with the PE extract at 3.91, 7.81, 15.63, 31.25, 62.5, 125, 250 and $500 \mu \mathrm{g} / \mathrm{ml}$, respectively, for 24,48 and $72 \mathrm{~h}$. Data presented as the mean \pm standard deviation of at least three experiments. PE, petroleum ether.

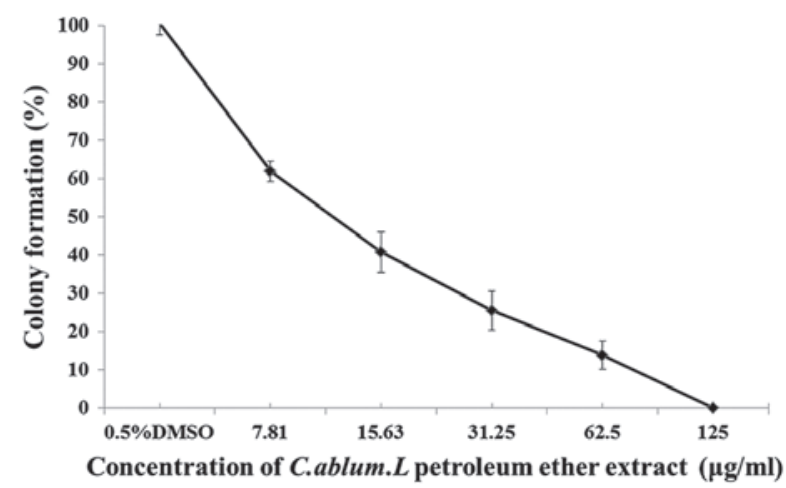

Figure 2. Inhibitory effects of the PE extract of Chenopodium album $\mathrm{L}$ on the colony formation of A549 cell. PE extract of Chenopodium album L. was administered at concentrations of 7.81, 15.63, 31.25 and 62.5 to $125 \mu \mathrm{g} / \mathrm{ml}$ and their cell colony formations were visualized by crystal violet staining and formaldehyde fixing after culturing for 12 days. 0.5\% DMSO treatment was the. Data presented as the mean \pm standard deviation of at least three experiments. PE, petroleum ether.

A549 cells exhibited G1 phase arrest and apoptosis after treatment with the PE extract of $C$. album $L$. To investigate the mechanism of the cell growth inhibitory effect induced by the PE extract on A549, the cell cycle of A549 cells was assessed following treatment with 31.25 and $62.5 \mu \mathrm{g} / \mathrm{ml} \mathrm{PE}$ extract for $24 \mathrm{~h}$. The results showed that these phytochemical treatments significantly increased the ratio of the G1 population of the cells (Fig. 5) in a concentration-dependent manner (untreated, 59.37\%; $31.25 \mu \mathrm{g} / \mathrm{ml}, 69.74 \%, \mathrm{P}<0.01 ; 62.5 \mu \mathrm{g} / \mathrm{ml}$, $76.93 \%, \mathrm{P}<0.001)$. 

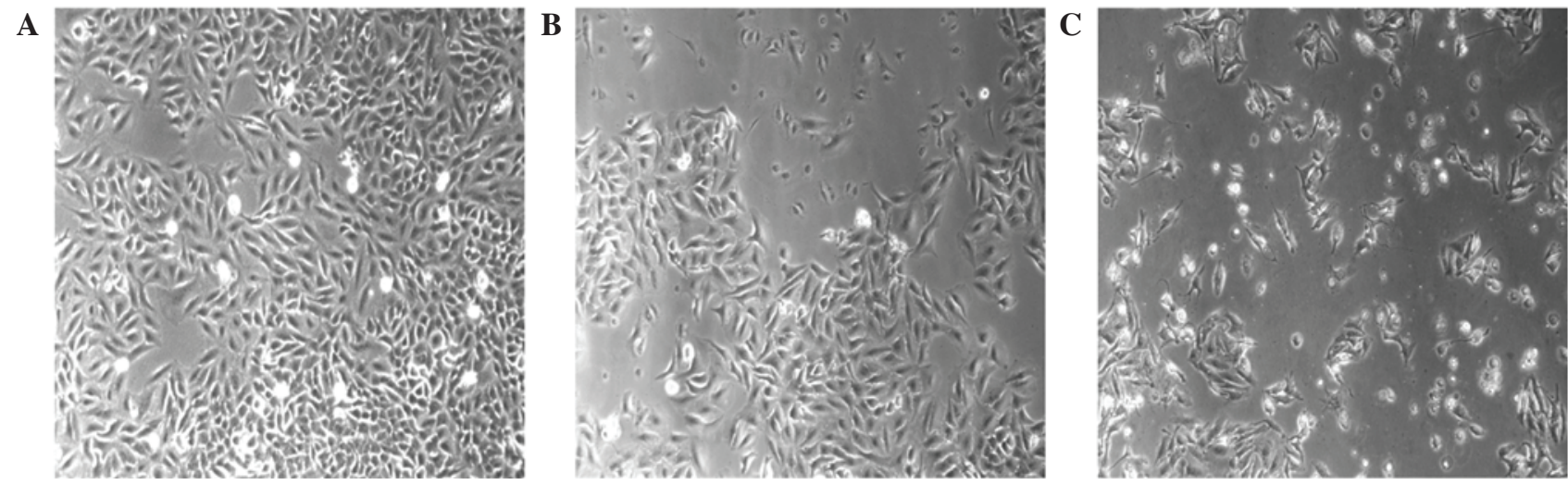

Figure 3. Morphological changes of A549 cells treated with the PE extract of Chenopodium album L or (A) 0.5\% DMSO as the control. A549 cells grew with the PE extract of Chenopodium album L. at concentrations of (B) 31.25 and (C) $62.5 \mu \mathrm{g} / \mathrm{ml}$ for $24 \mathrm{~h}$ and were visualized under a bright field using an inverted fluorescence microscope (magnification, x200). PE, petroleum ether.
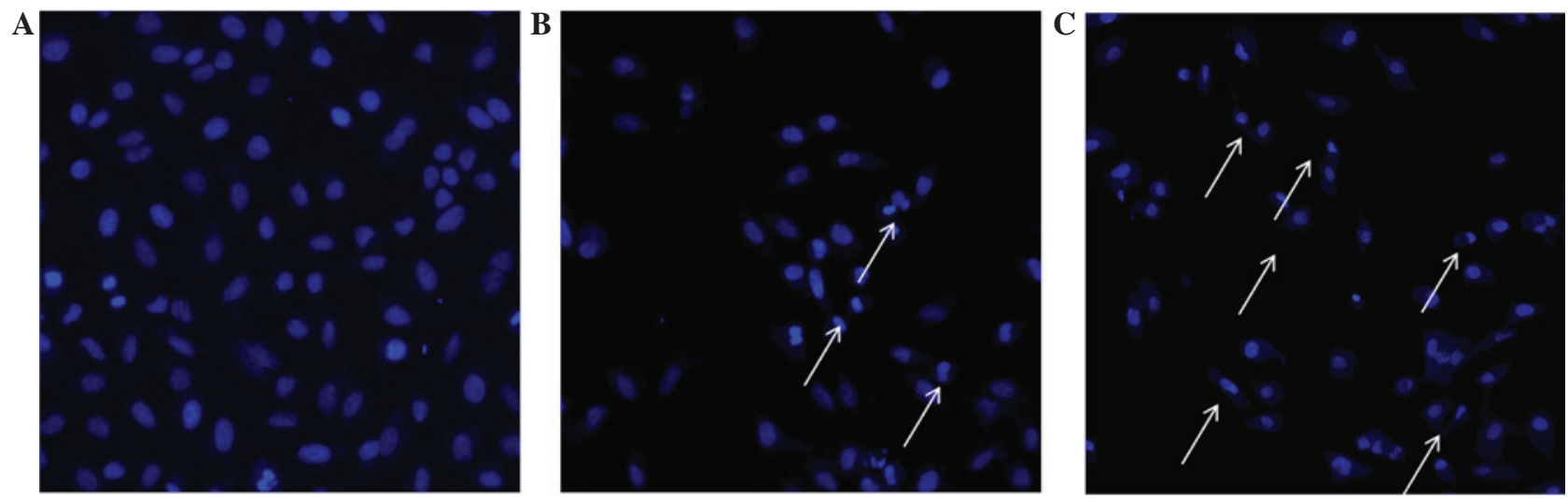

Figure 4. Morphological changes of the nucleus of A549 cells treated by the PE extract of Chenopodium album L or (A) $0.5 \%$ DMSO as the control. Nuclear morphological changes of A549 cells treated with the PE extract at concentrations of (B) 31.25 and (C) $62.5 \mu \mathrm{g} / \mathrm{ml}$ were visualized under an inverted fluorescence microscope (magnification, x200) for $24 \mathrm{~h}$. Arrows indicate nuclear compaction. PE, petroleum ether.

In addition, the effect of PE extract of C. album L. on cell apoptosis was assessed by measuring the ratio of apoptotic cells in the cell population following different PE extract treatments. PE extract-treated A549 cells were subjected to cell apoptosis analysis using a flow cytometer after the cells were stained by Annexin V-FICT/PI. The results showed that A549 cells treated with either 31.25 or $62.5 \mu \mathrm{g} / \mathrm{ml}$ of the PE extract for $24 \mathrm{~h}$ exhibited significant increases in the ratio of apoptotic cells in the cell population (untreated, $0.775 \% ; 31.25 \mu \mathrm{g} / \mathrm{ml}$, $11.9 \%, \mathrm{P}<0.001 ; 62.5 \mu \mathrm{g} / \mathrm{ml}, 22.3 \%, \mathrm{P}<0.001$; Fig. 6). These findings indicated that A549 cell growth inhibition following treatment with the PE extract of C. album L. may be associated with the induction of cell cycle G1 phase arrest and apoptosis.

\section{Discussion}

Chinese medicinal herbs have been widely been used as a folk medicine for centuries in China and southeast Asia (16-18). However, empirical studies related to the action mechanisms of the phytochemicals from these widely used Chinese medicinal herbs remain insufficient. Therefore, the present pilot study was initiated by building a small phytochemical extract library from $>50$ Chinese medicinal herbs, which was subsequently used as a platform to screen plant constituents of possible novel anticancer activities on an array of in vitro human cancer cell lines. This study specifically focused on the phytochemical extracts from C. album L. and explored their possible anticancer activities against human non-small cell lung cancer A549 cells. The present findings demonstrated for the first time that the PE extract of $C$. album L. significantly inhibited A549 cell growth in a time- and dose-dependent manner, as determined via MTT and colony formation assays.

Cancer cells generally evade the programmed cell death regulatory pathways of normal tissues to support their malignant growth $(19,20)$ and uncontrolled proliferation, thus the suppression of apoptosis has a key role in cancer development $(21,22)$. To date, various anti-cancer drugs targeting cancer cell apoptosis have been developed from natural chemicals $(23,16)$. The present study demonstrated that the PE extract of C. album L. affected the cellular morphology of human non-small cell lung cancer A549 cells, and their proliferative abilities. The present findings also showed that the phytochemical extract induced cellular apoptosis and G1 cell cycle arrest, which may provide important information to develop novel cancer therapies. To evaluate how the PE extract induced A549 cell apoptosis, the nuclear morphology of A549 cells treated with the extract was analyzed using Hoechst 33342 immunofluorescent staining, and the externalization of 
A

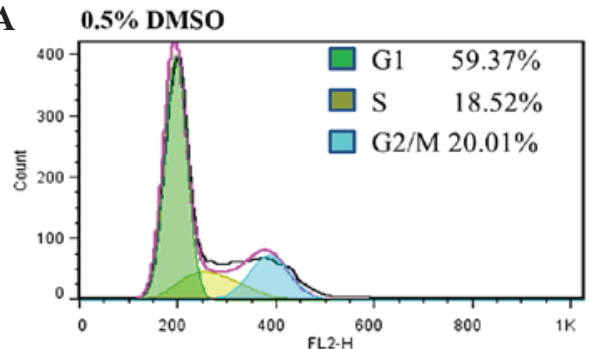

C

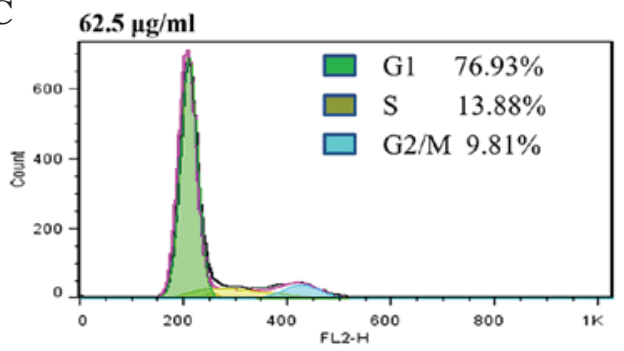

B

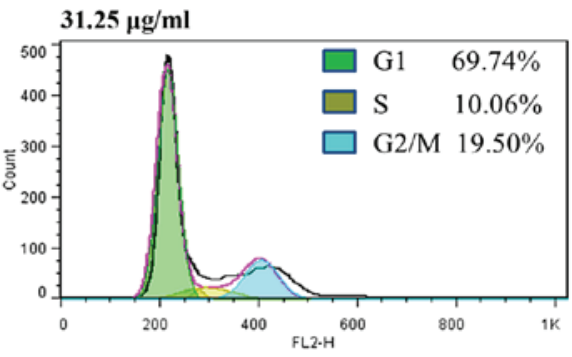

D

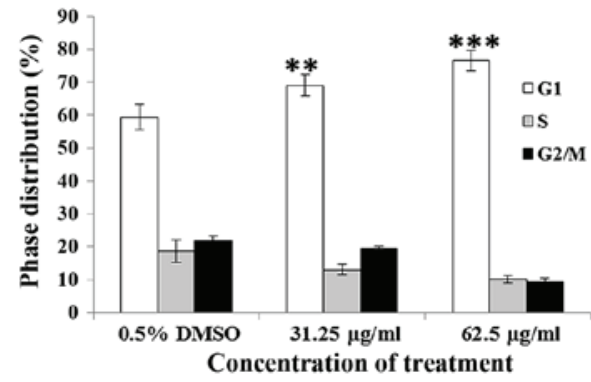

Figure 5. Cell cycle analysis of A549 cells cultured with (A) $0.5 \%$ DMSO (control), and (B) $31.25 \mu \mathrm{g} / \mathrm{ml}$ and (C) $62.5 \mu \mathrm{g} / \mathrm{ml}$ of petroleum ether extract of Chenopodium album $\mathrm{L}$. for $24 \mathrm{~h}$ using flow cytometry after the cells were stained by propidium iodide. (D) Histograms present the percentage of each cell populations at the different cell cycle stage following treatment. Data presented as the mean \pm standard deviation of at least three experiments. ${ }^{* *} \mathrm{P}<0.01$ and ${ }^{* * * *} \mathrm{P}<0.001$ vs. the controls.

A

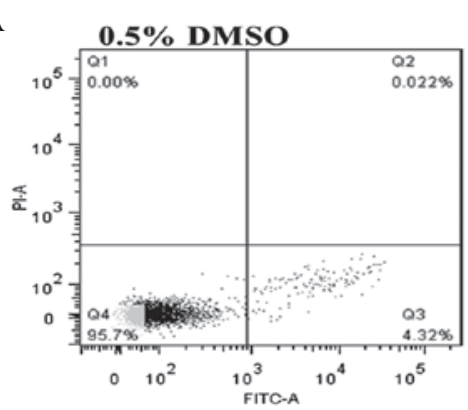

B

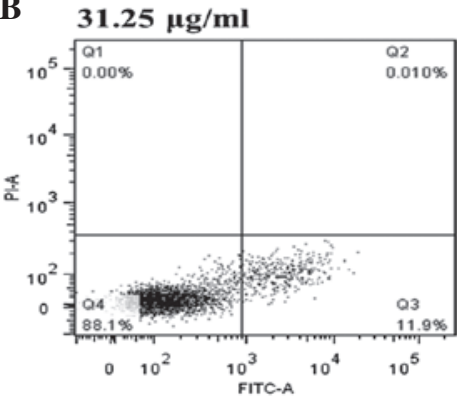

C

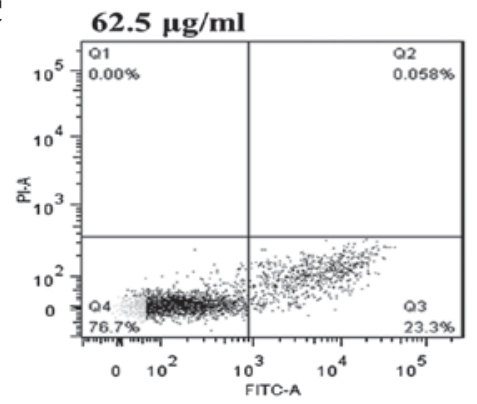

D

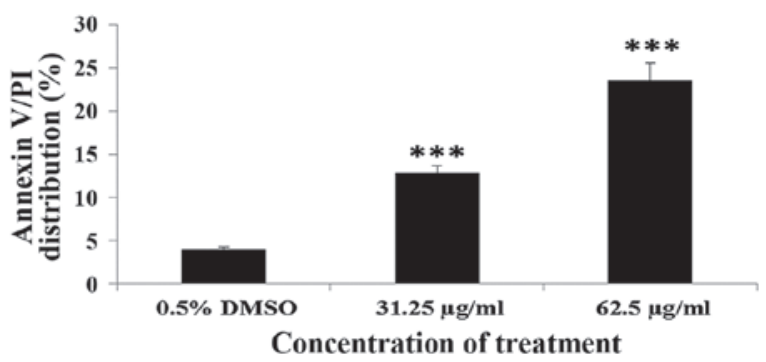

Figure 6. Apoptosis analysis of A549 cells treated with (A) $0.5 \%$ DMSO (as control), and (B) $31.25 \mu \mathrm{g} / \mathrm{ml}$ and (C) $62.5 \mu \mathrm{g} / \mathrm{ml}$ petroleum ether extract from Chenopodium album L. for $24 \mathrm{~h}$ by fluorescence-activated sorting using flow cytometry. (D) Percentages of apoptotic cells in A549 treated with petroleum ether extract at $31.25 \mu \mathrm{g} / \mathrm{ml}$ and $62.5 \mu \mathrm{g} / \mathrm{ml}$. Data presented as the mean \pm standard deviation of at least three experiments. ${ }^{* * *} \mathrm{P}<0.001 \mathrm{vs}$. the control. FITC, fluorescein isothiocyanate.

phosphatidylserine (PS) of A549 cells treated with the extract using the binding assay of Annexin V to PS followed by cell sorting with a flow cytometer $(24,25)$. The results indicated that the PE extract caused A549 cells to undergo chromatin condensation and externalization of PS, which are typical apoptotic phenotypes.

Cell cycle progress is crucial for cell proliferation $(26,27)$. G1 phase arrest of the cell cycle provides an opportunity for cells to either undergo repair or follow an apoptotic pathway $(28,29)$. Many chemicals developed as anti-tumor agents were designed to target cellular components involved in promoting G1/S transition $(30,31)$. The present results have shown that the PE extract of $C$. ambrosioides L. significantly induced G1 phase arrest of A549 cells, which may be one of the mechanisms to trigger the cell apoptosis. This provides an important base and opportunity to further characterize the natural molecule(s) associated with this significant biological activity in future research. 
At present, herbal medicines have been shown to be a promising approach for curing lung cancer $(32,33)$. Since our crude extract is an unfractionated plant extraction, it is possible that the components mediating cell death of different tumor cell are not identical. For a specific plant, different extraction processes may produce a variety of compounds with different concentrations and various bioactivities (34). The present results suggested that there may be valuable active compound(s) against human non-small cell lung cancer A549 cell in the PE extract of C. album L. At this stage, it is not possible to elucidate whether these effects on A549 cell growth are induced by specific compounds or are the result of the combined action of multiple compounds in the extract. As an edible Chinese medicinal herb, C. album L. has no toxicity and few side effects. C. album $\mathrm{L}$ is a wild neglected herb which has various pharmacological properties, such as antiviral, antifungal, anti-inflammatory, antiallergic, antiseptic and immunomodulating activities. However it has some side effects since it contains porphyrin. Any plant that contains such a substance belongs to the ling sensitivity plants; after people eat it and are then exposed to sunlight, they are prone to developing a skin disease called phytophotodermatitis (35). therefore, the plant can be consumed as a human food and is expected to benefit individuals with lung cancer (36).

In conclusion, the present study, for the first time, screened different phytochemical extracts from C. album L. against non-small cell lung cancer A549 cell to explore their anticancer activities, and demonstrated that the PE extract of C. album L. specifically inhibited A549 cell growth by inducing cell cycle G1 phase arrest and cell apoptosis. These results may provide valuable data for assessing the possible usage of phytochemicals from $C$. album L. in exploring and developing novel cancer therapies and healthcare products.

\section{Acknowledgements}

The present study was supported by the Key Subject Project Foundation for Natural Product and New Drug Research of Kunming University of Science and Technology (grant no. 14078183), the Personnel Training Project of Yunnan Province (grant nos. KKSY201226096 and KKSY201226097).

\section{References}

1. Siegel R, Naishadham D and Jemal A: Cancer statistics. Cancer J Clin 62: 10-29, 2013.

2. She J, Yang P, Hong QY and Bai CX: Lung cancer in China: Challenges and interventions. Chest 143: 1117-1126, 2013.

3. Verdeccchia A, Francisci S, Brenner H, Gatta G, Micheli A, Mangone L and Kunkler I; EUROCARE-4 Working Group: Recent cancer survival in Europe: A 2000-02 period analysis of EUROCARE-4 data. Lancet Oncol 8: 784-796, 2007.

4. Clardy J and Walsh C: Lesson from natural molecules. Nature 432: 829-837, 2004

5. Piggott AM and Karuso P: Quality, not quantity: The role of natural products and chemical proteomics in modern drug discovery. Comb Chem High Throughput Screen 7: 607-630, 2004.

6. Koch MA, Schuffenhauer A, Scheck M, Wetzel S, Casaulta S, Odermatt A, Ertl P and Waldmann H: Charting biologically relevant chemical space: A structural classification of natural products (SCONP). Proc Natl Acad Sci USA 102: 17272-17277, 2005 .
7. Hao XN, Chan SW and Chen SL: Detection of Puerarin and Danshensu in traditional Chinese medicinal preparation containing Pueraria lobata and Salvia Miltiorrhiza by high-performance liquid chromatography. J Liq Chromatogr Relat Technol 30: 2779-2787, 2007.

8. Hong JY, Nam JW, Seo EK and Lee SK: Daphnane diterpene esters with anti-proliferative activities against human lung cancer cells from Daphne genkwa. Chem Pharm Bull (Tokyo) 58: 234-237, 2010.

9. Toyang NJ, Ateh EN, Davis H, Tane P, Sondengam LB, Bryant J and Verpoorte R: In vivo antiprostate tumor potential of Vernonia guineensis Benth.(Asteraceae) tuber extract (VGDE) and the cytotoxicity of its major compound pentaisovaleryl sucrose. J Ethnopharmacol 150: 724-748, 2013.

10. Wang DS, Rizwani GH, Guo H, Ahmed M, Ahmed M, Hassan SZ, Hassan A, Chen ZS and Xu RH: Annona squamosa Linn: Cytotoxic activity found in leaf extract against human tumor cell lines. Pak J Pharm Sci 27: 1559-1563, 2014.

11. Kumar R, Mishra AK, Dubey NK and Tripathi YB: Evaluation of Chenopodium ambrosioides oil as a potential source of antifungal, antiaflatoxigenic and antioxidant activity. Int J Food Microbial 115: 159-164, 2007.

12. Kaur C and Kapoor HC: Antioxidant activity and total phenolic content of some Asian vegetables. J Food Sci Technol 37: 153-161, 2002.

13. Dai Y, Ye WC, Wang ZT, Matsuda H, Kubo M and But PPH: Antipruritic and antinociceptive effects of Chenopodium album L. in mice. J Ethnopharmacol 81: 245-250, 2002.

14. Khoobchandani M, Ojeswi BK, Sharma B and Srivastava MM: Chenopodium album prevents progression of cell growth and enhances cell toxicity in human breast cancer cell lines. Oxid Med Cell Longev 2: 160-165, 2009.

15. Li T, Pan H, Feng Y, Li HZ and Zhao Y: Bioactivity-guided isolation of anticancer constituents from Hedera nepalensis $\mathrm{K}$. S Afr J Bot 100: 87-93, 2015.

16. Cheng YL, Lee SC, Harn HJ, Huang HC and Chang WL: The extract of Hibiscus syriacus inducing apoptosis by activating p53 and AIF in human lung cancer cells. Am J Chin Med 36: 171-184, 2008.

17. Li WY, Chan SW, Guo DJ, Chung MK, Leung TY and Yu PH: Water extract of Rheum officinale Baill. induces apoptosis in human lung adenocarcinoma A549 and human breast cancer MCF-7 cell lines. J Ethnopharmacol 124: 251-256, 2009.

18. Qi F, Li A, Inagaki Y, Gao J, Li J, Kokudo N, Li XK and Tang W: Chinese herbal medicines as adjuvant treatment during chemo-or radio-therapy for cancer. Biosci Trends 4: 297-307, 2010.

19. Choi KS: Autophagy and cancer, Exp Mol Med 44: 109-120, 2012.

20. Hu YL, Jahangiri A, Delay M and Aghi MK: Tumor cell autophagy as an adaptiveresponse mediating resistance to treatments such as antiangiogenic therapy. Cancer Res 72: 4294-4299, 2012.

21. Hanahan D and Weinberg RA: The hallmarks of cancer. Cell 100: $57-70,2000$.

22. Evan GI and Vousden KH: Proliferation, cell cycle and apoptosis in cancer. Nature 411: 342-348, 2001.

23. Hu H, Ahn NS, Yang X,Lee YS and Kang KS: Ganoderma lucidum extract induces cell cycle arrest and apoptosis in MCF-7 human breast cancer cell. Int J Cancer 102: 250-253, 2002.

24. Johnson VL, Ko SC, Holmstrom TH, Eriksson JE and Chow SC: Effector caspases are dispensable for the early nuclear morphological changes during chemical-induced apoptosis. J Cell Sci 113: 2941-2953, 2000

25. van Engeland M, Ramaekers FC, Schutte $B$ and Reutelingsperger CP: A novel assay to measure loss of plasma membrane asymmetry during apoptosis of adherent cells in culture. Cytometry 24: 131-139, 1996.

26. Schultz DR and Harringto WJ Jr: Apoptosis: Programmed cell death at molecular level. Semin Arthritis Rheum 32: 345-369, 2003.

27. Lowe SW and Lin AW: Apoptosis in cancer. Carcinogenesis 21: 485-495, 2000.

28. Ong CS, Zhou J, Ong CN and Shen HM: Luteolin induces G1 arrest in human nasopharyngeal carcinoma cells via the Akt-GSK-3 $\beta$-Cyclin D1 pathway. Cancer Lett 298: 167-175, 2010.

29. Pitchakarn P, Suzuki S, Ogawa K, Pompimon W, Takahashi S, Asamoto M, Limtrakul P and Shirai T: Induction of G1 arrest and apoptosis in androgen-dependent human prostate cancer by Kuguacin J, a triterpenoid from Momordica charantia leaf. Cancer Lett 306: 142-150, 2011. 
30. Yano H, Mizoguchi A, Fukuda K, Haramaki M, Ogasawara S, Momosaki S and Kojiro M: The herbal medicine sho-saiko-to inhibits proliferation of cancer cell lines by inducing apoptosis and arrest at the G0/G1 phase. Cancer Res 54: 448-454, 1994.

31. Li Y, Ma HL, Han L, Liu WY, Zhao BX, Zhang SL and Miao JY: Novel ferrocenyl derivatives exert anti-cancer effect in human lung cancer cells in vitro via inducing G1-phase arrest and senescence. Acta Pharmacol Sin 34: 960-968, 2013.

32. Gao J, Morgan WA, Sanchez-Medina A and Corcoran O: The ethanol extract of Scutellaria baicalensis and the active compounds induce cell cycle arrest and apoptosis including upregulation of p53 and Bax in human lung cancer cells. Toxicol Appl Pharmacol 254: 221-228, 2011.
33. Tsai JC, Tsai S and Chang WC: Effect of ethanol extracts of three Chinese medicinal plants with laxative properties on ion transport of the rat intestinal epithelia. Biol Pharm Bull 27: 162-165, 2004.

34. Martins S, Mussatto SI, Martínez-Avila G, Montañez-Saenz J, Aguilar CN and Teixeira JA: Bioactive phenolic compounds: Production and extraction by solid-state fermentation. A review. Biotechnol Adv 29: 365-373, 2011.

35. Bilgili SG, Akdeniz N, Akbayram S, Ceylan A, Calka Ö and Karaman K: Phototoxic dermatitis due to Chenopodium album in a child. Pediatr Dermatol 28: 647-676, 2011.

36. Sun $\mathrm{CH}, \mathrm{Li}$ Y, He HY, Du W and Cheng XF: Nutritive compositions of Chenopodium album and the evaluation as a vegetable resource. Guihaia 25: 589-601, 2005. 